\title{
The Use Of Listen Read Discuss (LRD) Strategy To Improve Student's Reading Comprehension
}

\author{
Adelia1, Darmawan ${ }^{2}$ \\ 1,2 Faculty of Teacher Training and Education University of Taduloko \\ E-mail: darmawan1981@gmail.com
}

\begin{tabular}{l}
\hline Article Info \\
\hline Article History \\
Received: 2021-09-21 \\
Revised: 2021-10-28 \\
Published: 2021-11-09 \\
\\
Keywords: \\
Improving; \\
Reading Comprehensive; \\
Listen-Read-Discuss \\
Strategy.
\end{tabular}

Sejarah Artikel

Diterima: 2021-09-21

Direvisi: 2021-10-28

Dipublikasi: 2021-11-09

\section{Kata kunci:}

Meningkatkan;

Pemahaman Membaca

Strategi Dengarkan-Baca-

Diskusikan.

\begin{abstract}
The objective of this research is to find out whether the use of LRD Strategy can improve reading comprehension of grade ten students particularly in descriptive text. This researcher applied a quasi-experimental research design. The population of this research was grade ten students of SMK Negeri 6 Palu which consist of 108 students. The sample of this research was 36 students of class X TKJ 2 and considered as the experimental class while 36 students of class X TKJ 3 as the control class. The sample was selected using cluster random sampling technique. The technique of data collection was test that includes pre-test and post-test. While the mean score of pretest in experimental class was about 49.71, the control class is 58.09. In post-test, experimental class got 64.76. On the other hand, the control class got 61.13. By applying 0.05 level of significance and 28 degree of freedom (df), as seen tha table that the value of $t_{\text {-counted }}$ is (2.12) and $t_{\text {-table }}$ is (1.703). The $t_{\text {-counted }}$ value is higher than $t_{\text {-table, }}$ which means that the research hypothesis is accepted. Therefore, the use of LRD Strategy can improve students' reading comprehension in descriptive text.

Abstrak
Tujuan dari penelitian ini adalah untuk mengetahui apakah penggunaan Strategi LRD
dapat meningkatkan pemahaman membaca siswa kelas sepuluh khususnya dalam teks
deskriptif. Penelitian ini menggunakan desain penelitian quasi-experimental. Populasi
dalam penelitian ini adalah siswa kelas sepuluh SMK Negeri 6 Palu yang berjumlah 108
siswa. Sampel penelitian ini adalah 36 siswa kelas X TKJ 2 yang merupakan kelas
eksperimen sedangkan 36 siswa kelas X TKJ 3 sebagai kelas kontrol. Sampel dipilih
dengan menggunakan teknik cluster random sampling. Teknik pengumpulan datanya
adalah tes yang meliputi pre-test dan post-test. Sedangkan nilai rata-rata pre-test di
kelas eksperimen adalah 49,71, kelas kontrol adalah 58,09. Pada post-test, kelas
eksperimen mendapat 64,76 . Sedangkan kelas kontrol mendapat nilai 61,13 . Dengan
menerapkan taraf signifikansi 0,05 dan 28 derajat kebebasan (df), terlihat dari tabel
bahwa nilai t hitung adalah $(2,12)$ dan t tabel adalah $(1,703)$. Nilai thitung lebih besar
dari t tabel yang berarti hipotesis penelitian diterima. Oleh karena itu, penggunaan
Strategi LRD dapat meningkatkan pemahaman membaca siswa dalam teks deskriptif.
\end{abstract}

\section{INTRODUCTION}

Reading is one of important skill. It holds role to obtain information that is implied or not implied from the text. Reading is a complex skill which is complicated that covers or involves smaller series (Tarigan, 1986:7). It means that reading is the way to understand about the content of the text, The main target in reading is the students reading comprehension competence to comprehend the content as it is presented in the text. Today, reading is very essential skill that is very demanded in daily life. With the development of the internet around the world, students need to master reading comprehension in order to understand their knowledge, content of the text, articles, and so on, In recent years, the Indonesian ministry of education and cultural has been implementing a national curriculum called 2013 Curriculum. One of the objectives of this curriculum especially in English subject is that the students are expected to comprehend various kinds of reading texts, such as narrative, procedure, descriptive, factual report, and hortatory exposition (Permendikbud, 2016). As stated in the document that the concept of teaching reading is to gain one of the goals of 2013 Curriculum where students become independent reader (Mappiase \& bin Sishes, 2014). In consequence, English teachers are supposed to master the conceptual knowledge of curriculum and teaching reading to bring a good quality of teaching and learning process.

In fact, there are many difficulties and problems that students find in learning reading 
comprehension in terms of vocabulary, grammar and the way of understanding the main idea in the reading text. The difficulties may come from students' basic knowledge, attitude, situation, interest and teacher. It is suggested by Asmedy, (2018) and Asmedy, (2020) that to overcome students' difficulties in learning any subjects there must be suitable teaching strategies the teacher should apply that can support both students and teachers in teaching process.

Based on the preliminary observation conducted at SMK Negeri 6 Palu. The researchers found some problems related to the English teaching and learning process of reading comprehension, such as difficulties in answering comprehension question since they do not understand the contents of the text. Consequently, most students get very low scores in reading, In addition to that, the researchers also found a problematic situation where in teaching learning process particularly in reading activities students are only required to read the text without any understanding. The English teacher may just give the reading text to the students without knowing the students' level of comprehension. As a consequence, the English teacher does not know the difficulties of the students in reading comprehension,

Base on the problems above, the researchers would propose an alternative way to help students improve their reading comprehension which is Listen Read Discuss (LRD) strategy. Manzo and Casale (1985) stated that Listen Read Discuss (LRD) is a strategy that helps students to comprehend text. It is a comprehension strategy that develops students' primary knowledge they read a text. Manzo and Casale (1995:10) state the benefits of using LRD strategy as follows:

1) It helps students to comprehend the material presented orally

2) It builds students prior knowledge before they read a text

3) It engages struggling readers in classroom discussion.

Some related researches have been conducted previously. As Anggraeni (2014) investigated "The Reading Comprehension of The Eight Grade Students of SMPN 1 Puncakwangi Pati in The Academic Year 2013/2014 by using Listen Read Discuss (LRD)". This research focused on recount text. Based to the result, the application of Listen Read Discuss (LRD) Strategy is effective in teaching reading comprehension of the eight grade students of SMPN 1 Puncakwangi Pati in the academic year 2013/2014. Hutomo (2017) also studied the same issue with the research title is 'Improving The Students' Reading Comprehension Class XI IPA of SMA AL MUAYYAD Surakarta in 2016/2017 Academic Year." The research focused on report text. Based on the result, the use of Listen Read Discuss (LRD) strategy is effective to improve the students' reading comprehension particularly in report text. Having looked at the previous studies above, it seems that the class condition improves when the teacher implement LRD strategy. Therefore, it can be inferred that Listen Read Discuss (LRD) strategy is effective to improve students' reading comprehension at a different level. Accordingly, the researcher formulates a research question as follows: "Can using $L R D$ (listen, read, discuss) Strategy improve reading comprehension of grade ten students of SMK Negeri 6 Palu?"

\section{METHOD}

This research applied quasi experimental research design, specifically non-equivalent control group design. The researcher took one class as an experimental group and one class as a control group. Both groups were given pre-test and post-test, but only experimental group were given the treatment. In the experimental group, the researcher applied Listen Read Discuss Strategy as a strategy in teaching while in the control group, the researcher used Conventional Teaching Method. The design of this research was taken from Cohen et al., (2000:214) as follows:

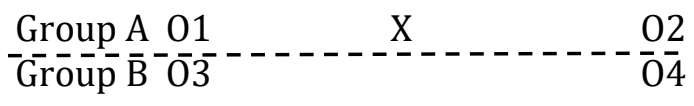

The population of this research was of grade ten students of SMK Negeri 16 Palu, consisting of three classes. The sample of this research are two classes of the population. The researcher used Cluster Random Sampling technique. In selecting the sample the researcher used lottery. Based on the process, the researcher got X TKJ 2 as the experimental class and X TKJ 3 as the control class, the researcher used the test as an instrument of the research in collecting the data. The test types in this research are multiple choices and essay. The test was divided into pretest and post-test. The pre-test was given in the first meeting for both classes to see the starting point before treatment while the post-test was given in the last meeting to measure students' 
reading comprehension and the progress after the treatment.

To find the result both of the classes the researcher used statistical analysis. First, the researcher computed the individual score by applying the formula proposed by Arikunto (2006:240). Second, the mean score of the students in pre-test and post-test computed by using formula recommended by Arikunto (2006). Then, after getting the individual score deviation, the square deviation to find out the significant difference between experimental and control group computed by using formula designed by Arikunto (2006:312). The last, to get the value of $t_{\text {counted }}$ in order to analyze the effectiveness of the treatment. The researcher applied t- test formula to show it. Arikunto (2006:311). The formula above as follows:

$$
\begin{aligned}
& \sum=\frac{x}{N} \times 100 \\
& \quad \text { Arikunto (2006:240) } \\
& M=\frac{\sum x}{N} \quad \text { Arikunto (2006) }
\end{aligned}
$$

a. Formula for the experimental group

$$
\sum x^{2}=\sum x^{2}-\frac{\left(\sum_{\chi}\right)^{2}}{N}
$$

b. Formula for the control group

$$
\sum y^{2}=\sum y^{2}-\frac{\left(\sum \mathrm{y}\right)^{2}}{N}
$$

By Arikunto (2006:312)

$$
t=\frac{M x-M y}{\sqrt{\left(\frac{\sum x^{2}+\sum y^{2}}{N x+N y-2}\right)\left(\frac{1}{N x}+\frac{1}{N y}\right)}}
$$

Arikunto (2006:311)

\section{RESULT AND DISCUSSION}

This research was conducted at SMK Negeri 6 Palu. The researcher used tests in collecting data from students in the experimental class and control class. In this research, test is used as the main instrument. The test was divided into two, they were pretest and posttest. The researcher gave the same pretest and posttest to the classes. The pretest was given before the treatment. The purpose of pre-test is to measure the students' reading comprehension before treatment. Whereas the post-test was conducted after the treatment. The purpose of the posttest is to measure the achievement of the students' reading comprehension. The researcher chose virtual teaching in applying this research due to pandemic covid-19 situation that require students to learn from home. The results of each test from both experimental dan control class was compared to find out the significant different. The result of the pre-test and post-test of experimental class is presented in table 1 .

Table 1. Result of the Pre-test and Post-test of Experimental Class

\begin{tabular}{rrr}
\hline \multirow{2}{*}{ No } & \multicolumn{2}{c}{ Students' Score } \\
\cline { 2 - 3 } & Posttest & Pretest \\
\hline 1 & 48.57 & 60.00 \\
\hline 2 & 60.00 & 54.28 \\
\hline 3 & 74.28 & 60.00 \\
\hline 4 & 68.57 & 45.71 \\
\hline 5 & 62.86 & 51.43 \\
\hline 6 & 80.00 & 54.28 \\
\hline 7 & 57.14 & 48.57 \\
\hline 8 & 48.57 & 28.57 \\
\hline 9 & 77.14 & 68.57 \\
\hline 10 & 97.14 & 60.00 \\
\hline 11 & 77.14 & 57.14 \\
\hline 12 & 22.86 & 17.14 \\
\hline 13 & 60.00 & 31.43 \\
\hline 14 & 45.71 & 42.86 \\
\hline 15 & 91.43 & 65.71 \\
\hline & $\mathbf{9 7 1 . 4 1}$ & $\mathbf{7 4 5 . 6 9}$ \\
\hline & $\mathbf{6 4 . 7 6}$ & $\mathbf{4 9 . 7 1}$ \\
\hline
\end{tabular}

By looking the table above, the result of students' pre-test showed that the highest score was 68.57 while the lowest score was 17.14 . The total score of students in the pre-test was 745.69. Then, the mean score achieved by the experimental class in the pre-test was 49.71, After the researcher applied the treatment, the post-test results of students in the experimental class as shown in table above, it is indicated that the highest score of the post-test in the experimental class was 97.14, and the lowest score was 22.86. The result of the pre-test and post-test of control class is presented on table 2 .

Table 2. Result of the Pre-test and Post-test of Control Class

\begin{tabular}{ccc}
\hline \multirow{2}{*}{ No } & \multicolumn{2}{c}{ Students' Score } \\
\cline { 2 - 3 } & Posttest & Pretest \\
\hline 1 & 65.71 & 54.28 \\
\hline 2 & 74.28 & 51.43 \\
\hline 3 & 51.43 & 77.14 \\
\hline 4 & 71.42 & 80.00 \\
\hline 5 & 62.86 & 34.28 \\
\hline
\end{tabular}




\begin{tabular}{crr}
\hline \hline 6 & 37.14 & 45.71 \\
\hline 7 & 34.28 & 54.28 \\
\hline 8 & 54.28 & 48.57 \\
\hline 9 & 65.71 & 34.28 \\
\hline 10 & 68.57 & 85.71 \\
\hline 11 & 45.71 & 57.14 \\
\hline 12 & 77.14 & 60.00 \\
\hline 13 & 45.71 & 40.00 \\
\hline 14 & 85.71 & 91.43 \\
\hline 15 & 77.14 & 57.14 \\
\hline Total & $\mathbf{9 1 7 . 0 9}$ & $\mathbf{8 7 1 . 3 9}$ \\
\hline Mean & $\mathbf{6 1 . 1 3}$ & $\mathbf{5 8 . 0 9}$ \\
\hline
\end{tabular}

reading comprehension of grade ten students of SMK Negeri 6 Palu. In this study, students' literal reading comprehension on descriptive text becomes the main focus of LRD implementation. During the treatment descriptive text was taught, as well as simple present tense, and action verbs. The generic structure of the text was also discussed.

Since pandemic covid-19 is not over yet, the treatment of teaching was conducted using an online platform which is whatsapp messenger. This research consisted one pre-test, six meetings of treatment, and one post-test. In pretest and post-test, the researcher provided a Google Form platform to facilitate students in collecting their pretest and posttest. The first test was a pretest. The goal was to determine the students' prior knowledge on comprehending reading material, the result of pretest from experimental class showed that the students' score in multiple choices was 96, in essay was 165 , and the mean score was 49.71. In the posttest their total score in multiple choices was 99, in essay was 241, and the mean score was 64.76. Having looked at this result, it is considered that there is an improvement on students' reading comprehension. This result is similar to the previous study from Anggraeni (2014) and Hutomo (2017) where both concluded that the use of LRD is effective to improve students reading comprehension.

By looking at the current situation, this research seems different from previous research before where previous researchers conducted an offline class to do a treatment, but this research was conducted virtually. This is the first time this strategy has been taught by online learning. The researcher totally realized by using online learning has some problems and shortcomings in its application. During six meetings the researchers gave treatment, the researcher found some problems in implementing this strategy in teaching learning process which is highly dependent on internet connectivity. The problem also comes from students, the students did not have data for internet connection so that it affected their presence. They often join very late during online class and this situation cannot be controlled by the researchers. To overcome this problem, the researcher made learning videos that students could access at any time so they did not miss the lesson and could ask the researcher either in class groups or ask the researcher directly. during and after the treatment whether or not LRD (listen, read, discuss) strategy can improve 
Another problem regarding the collection of student tasks and assignments that is time. Students were rarely turn in on time due to unsupported internet connection. To control this situation, the researchers prepared assignments and exercises in a platform called Google form to collect the students' assignments which they can open and fill it anytime and anywhere. The researchers shared their tasks directly on the link and the researcher set time limit for them to submit their assignment, based on the findings of this research and the previous research with same strategy, the researcher can conclude that Listen Read Discuss Strategy both taught in face to face class or through online class are equally can improve reading comprehension of grade ten students of SMK Negeri 6 Palu.

\section{CONCLUSION}

Using Listen Read Discuss (LRD) Strategy can improve reading comprehension of grade ten students of SMK Negeri 6 Palu because the students' reading comprehension has improved after applying this strategy. It was shown by looking the mean score of posttest in experimental class (64.76) and in the control class (61.13). There was significant difference between the main values of score in experimental group's posttest and control group's posttest. It is proved since t-counted (2.12) was higher than the t-table (1.703).

\section{REFERENCES}

Anggraeni, M. B. (2014). The Reading Comprehension of the Eight Grade Students of SMPN 1 Puncakwangi Pati in the Academic Year 2013/2014 Taught by Using LRD (Listen Read Discuss). [Online]. Retrieved from https://eprints.umk.ac.id/3105/1/Hal jud ul.pdf [November 04, 2019]

Arikunto, S. (2006). Metode Penelitian Kualitatif. Jakarta: Bumi Aksara.

Arikunto,S. (2006). Prosedur Penelitian Suatu Pendekatan Praktik. Jakarta: Rineka Cipta.

Asmedy. (2018). Pengembangan Perangkat Pembelajaran Bangun Datar dengan Pendekatan Open Ended.JIIP - Jurnal Ilmiah Ilmu Pendidikan, 1(2), 66-72. Retrieved from http://jiip.stkipyapisdompu.ac.id/jiip/inde x.php/IIIP/article/view/11
Asmedy. (2020). Perbandingan Hasil Belajar Connected Mathematics Project (CMP) dengan Pembelajaran Konvensional Pada Pokok Bahasan Geometri. JIIP - Jurnal Ilmiah Ilmu Pendidikan,3(1), 456-464. Retrieved from http://jiip.stkipyapisdompu.ac.id/jiip/inde x.php/IIIP/article/view/131

Cohen, L., Manion, L. and Morrison, K. (2000). Research Methods in Education. 5thEdition, Routledge Falmer, London. http://dx.doi.org/10.4324/978020322434 $\underline{2}$

Hutomo. I. A. (2017). Improving The Students' Reading Comprehension Class XI IPA of SMA $A L$ MUAYYAD Surakarta. [Online]. Retrieved from https://id.scribd.com/document/4049994 99/488-1721-1-PB [November 04, 2019]

Manzo, A \& Manzo, U. C. (2005). Teaching Children to be Literature: A Reflective Approach. Florida: Ted Buchhoz.

Manzo, A.V \& Casale, U. P. (1985). Listen-ReadDiscuss: A content reading heuristic. Journal of Reading, 28, 372-734.

Mappiase, S.S., \& bib Shishes, A.A (2014). Evaluation of English as a Foreign Language and its Curriculum in Indonesia. English Language Teaching, 8(10)., 113121.

Peraturan Menteri Pendidikan Nasional Republik Indonesia Nomor 22 Tahun 2016 tentang Standar isi untuk Satuan Pendidikan Dasar dan Menengah.

Tarigan, H. G., (1986). Menyimak Sebagai Suatu Keterampilan Berbahasa. Angkasa Bandung. 